Financiamento e conflito de interesses

\begin{tabular}{|c|c|c|c|c|c|c|c|}
\hline $\begin{array}{c}\text { Membro do grupo } \\
\text { de autores }\end{array}$ & $\begin{array}{l}\text { Local de } \\
\text { trabalho }\end{array}$ & $\begin{array}{l}\text { Verba de } \\
\text { pesquisa }{ }^{1}\end{array}$ & $\begin{array}{c}\text { Outro apoio à } \\
\text { pesquisa ou educação } \\
\text { médica continuada }^{2}\end{array}$ & $\begin{array}{c}\text { Honorários } \\
\text { de } \\
\text { palestrantes }\end{array}$ & $\begin{array}{l}\text { Participação } \\
\text { acionária }\end{array}$ & $\begin{array}{c}\text { Consultorl } \\
\text { conselho } \\
\text { consultivo }\end{array}$ & Outro \\
\hline Suzi Roseli Kerber & UFRGS & - & - & - & - & - & - \\
\hline Olga Garcia Falceto & UFRGS & - & - & - & - & - & - \\
\hline $\begin{array}{l}\text { Carmen Luiza C. } \\
\text { Fernandes }\end{array}$ & $\begin{array}{c}\text { Grupo } \\
\text { Hospitalar } \\
\text { Conceição }\end{array}$ & - & - & - & - & - & - \\
\hline
\end{tabular}

* Modesto

** Significativa

*** Significativa. Montantes fornecidos à instituição do autor ou a colega onde o autor tem participação, não diretamente ao autor.

Nota: UFRGS = Universidade Federal do Rio Grande do Sul

Mais informações consultar as Instruções aos Autores.

Referências

1. Coutinho DS, Baptista MN, Morais PR. Depressão pós-parto: prevalência e correlação com suporte social. Infanto Rev Neuropsiquiátr Infânc Adolesc. 2002;10(2):63-71.

2. Cruz EBS, Simōes GL, Faisal-Cury A. Post-partum depression screening among women attended by the Family Health Program. Rev Bras Ginecol Obstet. 2005;27(4):181-8.

3. Falceto OG, GiuglianI E, Fernandes CL. Couples' Relationships and breastfeeding: is there an association? J Hum Lact. 2004;20(1):46-55.
4. Hollist CS, Miller RB, Falceto OG, Fernandes CL. Marital satisfaction and depression: a replication of the Marital Discord Model in a Latino Sample. Fam Process. 2007;46(4)485-98.

5. Pinsof WM, Wynne LC. The effectiveness and efficacy of marital and family therapy: introduction to the special issue. J Mar Fam Ther. $1995 ; 21(4): 341-2$

\section{Bipolar disorder and multiple sclerosis: comorbidity and risk factors}

\section{Transtorno bipolar e esclerose múltipla: comorbidade e fatores de risco}

Dear Editor,

Multiple sclerosis (MS) is a demyelinating central nervous system (CNS) disease that affects mainly young adults. The disease course is unpredictable, and clinical manifestations include motor deficits, sensory changes, bladder and bowel dysfunction, uni- optical neuritis, diplopia, and cerebellar signs. Rarely, MS may initially present itself as a manic syndrome, similar to that observed in bipolar disorder (BD). ${ }^{1}$ We report a patient diagnosed with BD who was later diagnosed with MS. The possibility of mania as a symptom or comorbidity of MS was examined in this case report to assess possible risk factors.

\section{Case report}

The patient, JPS, is a 50-year-old divorced female. In 1999, she developed euphoria, irritability, impulsivity, and grandiose delusions. For example, she started taking various classes to achieve grandiose goals, pursuing unrealistic business ideas, acquired several debts that she could not repay, requested dismissal from her employment because she believed she would become a millionaire, exhibited inappropriate seductive behavior, and placed an advertisement in a newspaper offering call girl services that resulted in the termination of her marriage. At that time, her relatives noticed that she was experiencing psychomotor agitation, aggressiveness, auditory hallucinations and delirious ideas; she was admitted to a psychiatric clinic for treatment, and her psychotic symptoms subsequently went into remission with the use of haloperidol plus promethazine. After six months, she presented with daily sadness, anhedonia, psychomotor retardation and fatigue; these symptoms were resolved with $20 \mathrm{mg} /$ day of fluoxetine. In 2000, she developed a subacute motor deficit on her left side and gait impairment, both of which partially improved spontaneously. At that time, her CT scan was normal. In 2001, she developed urinary incontinence and was referred for neurological assessment. A clinical examination revealed left hemiparesis, spasticity, and tendon reflexes that were brisk on the left side, and normal on the right side. Her cutaneous-plantar reflex was equivocal on the left side and resulted in toe flexion on the right side, and her gait was hemiparetic on the left side. The remainder of the neurological examination was normal. Magnetic resonance imaging (MRI) of her brain showed demyelinating periventricular lesions (Figure 1). An MRI scan of her cervical cord also showed demyelinating lesions. Autoantibody (anti-Ro, anti-LA, anti-Sm, ANA, anti-DNA and anticardiolipin) and serology (syphilis, hepatitis B and C, HIV and HTLV) tests were negative. Analysis of the cerebrospinal fluid (CSF) detected the presence of oligoclonal bands. Visual evoked potentials showed increased latencies and reduced amplitudes. Based on these findings, the patient was diagnosed with MS, and treatment was initiated with interferon beta-1A. During the nine years of 


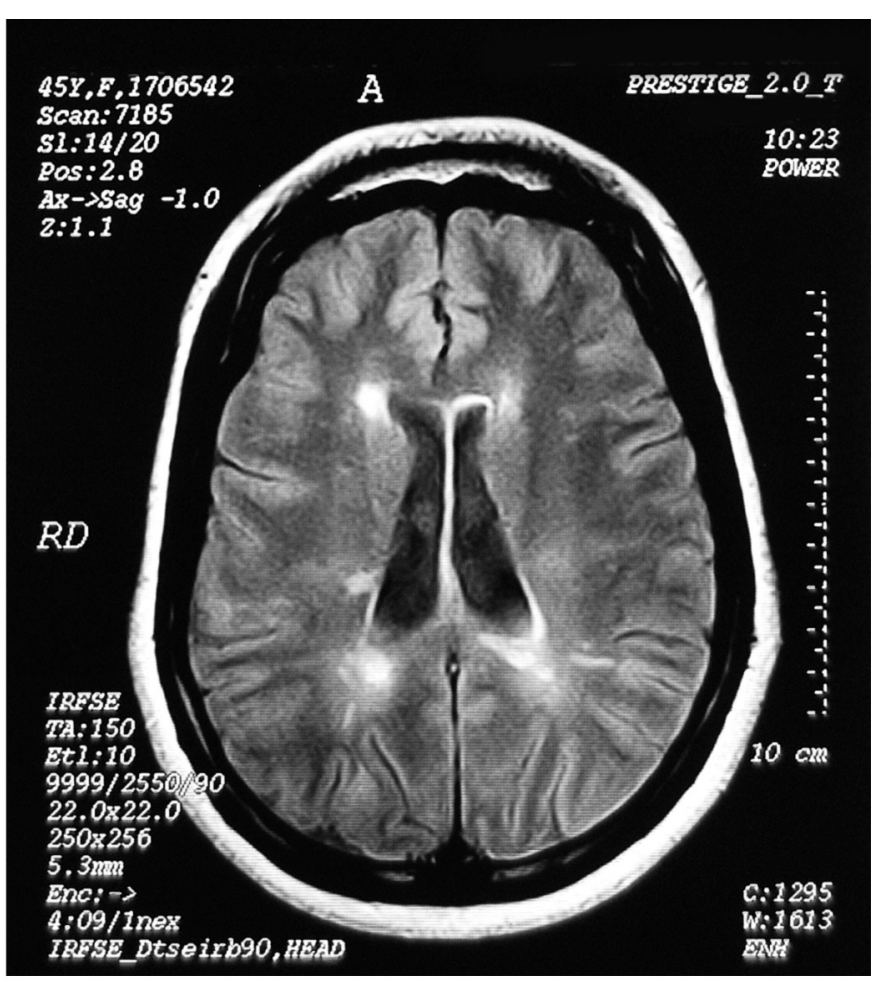

Figure 1 - Brain MRI axial section, showing demyelinating periventricular lesions in a patient presenting bipolar disorder and multiple sclerosis.

follow-up, the patient did not present any episodes suggestive of a mood disorder despite treatment with interferon beta, but she experienced worsening symptoms of her neurological disease. Neuroimaging studies revealed subsequent appearance of new lesions, mainly in the corpus callosum and in the callous-septal interface. Treatment with interferon was discontinued due to the severity of her disability.

\section{Discussion}

The association between mood disorders and MS has been described by several studies. There is evidence that this population is more susceptible to BD. An epidemiological study conducted by Schiffer et al. showed that $\mathrm{BD}$ is twice as common in patients with MS than in the general population. ${ }^{2}$ Joffe et al. showed that $13 \%$ of an outpatient sample of patients with MS were diagnosed with $\mathrm{BD} .^{3}$ In these two studies, patients with a history of hypomania/ mania episodes due to corticosteroid use were excluded. Using MRI, Lyoo et al. systematically evaluated 2,783 individuals who had been referred for psychiatric hospitalization and found changes in white matter that were compatible with the neuroradiological criteria of MS in 23 patients $(0.83 \%) .{ }^{4}$ The mechanisms underlying these associations are unknown and have been poorly investigated to date. Family studies investigating the involvement of HLA (human leukocyte antigen) genes have demonstrated a common genetic susceptibility among patients with BD and MS. ${ }^{5}$

We described a patient diagnosed with $\mathrm{BD}$ according to the DSM-IV-TR who was later diagnosed with MS according to the
MacDonald criteria. Because a detailed neurological examination was not available at the onset of this case, it is impossible to assert that the patient's mania was a symptom of MS. However, the absence of a personal or family history of $\mathrm{BD}$ and the late onset of symptoms raises this possibility.

\section{Ana Claudia Rodrigues de Cerqueira,} Antônio Egídio Nardi

Laboratory of Panic and Respiration, Institute of Psychiatry, Universidade Federal do Rio de Janeiro (UFRJ),

Rio de Janeiro, RJ, Brazil

National Institute for Translational Medicine (INCT-TM)

Fabiana Souza-Lima, José Maurício Godoy-Barreiros Department of Neurology, Universidade do Estado do Rio de Janeiro (UERJ), Rio de Janeiro, RJ, Brazil 


\begin{tabular}{|c|c|c|c|c|c|c|c|}
\hline $\begin{array}{l}\text { Writing group } \\
\text { member }\end{array}$ & Employment & $\begin{array}{l}\text { Research } \\
\text { grant }^{1}\end{array}$ & $\begin{array}{l}\text { Other research grant } \\
\text { or medical } \\
\text { continuous } \\
\text { education }{ }^{2}\end{array}$ & $\begin{array}{l}\text { Speaker's } \\
\text { honoraria }\end{array}$ & $\begin{array}{c}\text { Ownership } \\
\text { interest }\end{array}$ & $\begin{array}{l}\text { Consultant/ } \\
\text { Advisory } \\
\text { board }\end{array}$ & Other $^{3}$ \\
\hline $\begin{array}{l}\text { Ana Claudia } \\
\text { Rodrigues de } \\
\text { Cerqueira }\end{array}$ & UFRJ & $\mathrm{CNPq}^{* *}$ & - & - & - & - & - \\
\hline $\begin{array}{l}\text { Antônio Egídio } \\
\text { Nardi }\end{array}$ & UFRJ & $\mathrm{CNPq}^{* *}$ & - & $\begin{array}{l}\text { Glaxo- } \\
\text { Smitkline* } \\
\text { Roche* }^{*}\end{array}$ & - & Aché* & ArtMed $^{*}$ \\
\hline $\begin{array}{l}\text { Fabiana Souza- } \\
\text { Lima }\end{array}$ & UERJ & - & - & - & - & - & - \\
\hline $\begin{array}{l}\text { José Maurício } \\
\text { Godoy- } \\
\text { Barreiros }\end{array}$ & UERJ & - & - & - & - & - & - \\
\hline \multicolumn{8}{|c|}{$\begin{array}{l}\text { * Modest } \\
{ }_{* *}^{*} \text { Significant } \\
\text { *** Significant: Amounts given to the author's institution or to a colleague for research in which the author has participation, not directly to the } \\
\text { author. } \\
\text { Note: UFRJ = Universidade Federal do Rio de Janeiro; UERJ = Universidade do Estado do Rio de Janeiro; CNPq = Conselho nacional de } \\
\text { Desenvolvimento Científico e Tecnológico. } \\
\text { For more information, see Instructions for Authors. }\end{array}$} \\
\hline
\end{tabular}

References

1. Asghar-Ali AA, Taber KH, Hurley RA, Hayman LA. Pure neuropsychiatric presentation of multiple sclerosis. Am J Psychiatry. 2004;161(2):226-31.

2. Schiffer RB, Wineman NM, Weitkamp LR. Association between bipolar affective disorder and multiple sclerosis. Am J Psychiatry. 1986;143(1):94-5.

3. Joffe RT, Lippert GP, Gray TA, Sawa G, Horvath Z. Mood disorders and multiple sclerosis. Arch Neurol. 1987;44(4):376-8.

\section{Qual a verdadeira associação entre disfunção cognitiva e o uso da cannabis?}

\section{What is the really association between cognitive disfunction and cannabis?}

Prezado Editor,

Foi com grande interesse que lemos o artigo de revisão "Anormalidades cognitivas no uso da cannabis" publicado no primeiro suplemento da Revista Brasileira de Psiquiatria de 2010. ${ }^{1} \mathrm{O}$ artigo trata de forma bem objetiva a possibilidade de prejuízos cognitivos irreversíveis com o uso da cannabis. Por ser a droga ilícita mais usada no mundo, o estudo de tais déficits é de extrema importância. ${ }^{1}$

De forma sumária, os autores sugerem que o uso crônico da cannabis causa alteraçōes que podem ser persistentes, mesmo após a cessação do uso, em diversas funções cognitivas. Estes efeitos seriam ainda piores em usuários pesados e com início do uso na adolescência. ${ }^{1}$
4. Lyoo IK, Seol HY, Byun HS, Renshaw PF. Unsuspected multiple sclerosis in patients with psychiatric disorders: a magnetic resonance imaging study. J Neuropsychiatry Clin Neurosci. 1996;8(1):54-9.

5. Schiffer RB, Weitkamp LR, Wineman NM, Guttornsem S. Multiple sclerosis and affective disorder: family history, sex, and HLA-DR antigens. Arch Neurol. 1988;45(12):1345-8.

A partir destes dados, temos algumas ressalvas a fazer. Uma variável que não é avaliada em nenhum estudo e que pode confundir os achados trata-se das disfunçōes cognitivas pregressas ao uso da droga, resultando na busca e experimento da mesma. Algumas disfunçôes cognitivas como, por exemplo, dificuldades na tomada de decisões, poderiam propiciar o primeiro contato com a droga, e não o próprio uso causar o prejuízo da mesma. Estas considerações poderiam justificar o elevado uso de drogas lícitas e ilícitas em diversos transtornos psiquiátricos como, por exemplo, o transtorno bipolar do humor, esquizofrenia e o transtorno de personalidade antissocial. ${ }^{2-4}$ Nestes transtornos, alteraçôes neuroanatômicas e neurofuncionais conhecidas, com suas consequentes disfunções cognitivas, poderiam justificar o elevado uso de substâncias psicoativas por parte dos pacientes. ${ }^{2,3}$

Resultados preliminares de uma coorte realizada por nós mostram que disfunções neuropsicológicas pregressas estão associadas à busca pela cannabis. Estudamos um grupo de 124 adolescentes (entre 13 e 14 anos) sem transtornos psiquiátricos (avaliados pelo MINIPLUS) e sem história de uso de drogas ilícitas. Além de avaliarmos dados sociodemográficos e inteligência (avaliada pelo teste de Escalas Progressivas de Raven), aplicamos a Barratt Impulsiveness Scale (BIS-11), uma escala de autopreenchimento que avalia a impulsividade do indivíduo como um todo, além de três categorias distintas: impulsividade motora, impulsividade 